\title{
FORTY-SEVENTH ANNUAL LIST OF PAPERS
}

\author{
READ BEFORE THE AMERICAN MATHEMATICAL SOCIETY AND SUBSEQUENTLY \\ PUBLISHED, INCLUDING REFERENCE TO THE PLACES OF PUBLICATION
}

Adkisson, V. W. Plane peanian continua with unique maps on the sphere and in the plane. Read Sept. 9, 1937. Transactions of this Society, vol. 44, no. 1 (July, 1938), pp. 58-67.

See MacLane, Saunders.

Agnew, R. P. Linear functionals satisfying prescribed conditions. Read Oct. 30, 1937. Duke Mathematical Journal, vol. 4, no. 1 (March, 1938), pp. 55-77.

Comparison of products of methods of summability. Read Feb. 20,1937. Transactions of this Society, vol. 43, no. 3 (May, 1938), pp. 327-343.

Agnew, R. P., and Morse, A. P. Extensions of linear functionals, with applications to limits, integrals, measures, and densities. Read Sept. 10, 1937. Annals of Mathematics, (2), vol. 39, no. 1 (Jan., 1938), pp. 20-30.

Ahlfors, L. V. An extension of Schwarz's lemma. Read Sept. 8, 1937. Transactions of this Society, vol. 43, no. 3 (May, 1938), pp. 359-364.

Albert, A. A. Quadratic null forms over a function field. Read Dec. 29, 1937. Annals of Mathematics, (2), vol. 39, no. 2 (April, 1938), pp. 494-505.

- A quadratic form problem in the calculus of variations. Read Nov. 27, 1937. This Bulletin, vol. 44, no. 4 (April, 1938), pp. 250-253.

- Symmetric and alternate matrices in an arbitrary field. I. Read April 10, 1937. Transactions of this Society, vol. 43, no. 3 (May, 1938), pp. 386-436.

On cyclic algebras. Read April 9, 1938. Annals of Mathematics, (2), vol. 39, no. 3 (July, 1938), pp. 669-682.

- Non-cyclic algebras with pure maximal subfields. Read Feb. 26, 1938. This Bulletin, vol. 44, no. 8 (Aug., 1938), pp. 576-579.

A note on normal division algebras of prime degree. Read April 9, 1938. This Bulletin, vol. 44, no. 10 (Oct., 1938), pp. 649-652.

Baer, Reinhold. Groups with abelian central quotient group. Read Sept. 7, 1937. Transactions of this Society, vol. 44, no. 3 (Nov., 1938), pp. 357-386.

- Groups with preassigned central and central quotient group. Read Sept. 10, 1937. Transactions of this Society, vol. 44, no. 3 (Nov., 1938), pp. 387-413.

- The applicability of lattice theory to group theory. Read April 15, 1938. This Bulletin, vol. 44, no. 12 (Dec., 1938), pp. 817-820.

Baker, G. A. Correlation surfaces of two or more indices when the components of the indices are normally distributed. Read April 9, 1938. Annals of Mathematical Statistics, vol. 8, no. 4 (Dec., 1937), pp. 179-182.

Basoco, M. A. Arithmetized expansions for certain pseudo-periodic functions. Read Nov. 30, 1934. Giornale di Matematiche, vol. 73 (1935), pp. 105-114.

Bateman, Harry. Halley's methods for solving of equations. Read Sept. 10, 1937. American Mathematical Monthly, vol. 45, no. 1 (Jan., 1938), pp. 11-17.

Beckenbach, E. F. Remarks on the problem of Plateau. Read Sept. 10, 1937. Duke Mathematical Journal, vol. 3, no. 4 (Dec., 1937), pp. 676-681.

- On a theorem of Fejér and Riesz. Read Sept. 3, 1936. Journal of the London Mathematical Society, vol. 13, no. 2 (April, 1938), pp. 82-86.

- A relative of the lemma of Schwarz. Read Dec. 28, 1937. This Bulletin, vol. 44, no. 10 (Oct., 1938), pp. 698-707.

Bell, Clifford. Mathematics of finance of the past and present. Read Dec. 2, 1933. Scientia, (3), vol. 62, no. 12 (Dec., 1937), pp. 321-325. 
Bell, E. T. Notes on denumerants. Read Nov. 27, 1937. Journal of the Indian Mathematical Society, vol. 3, no. 2 (June, 1938), pp. 41-45.

The iterated exponential integers. Read Nov. 27, 1937. Annals of Mathematics, (2), vol. 39 , no. 3 (July, 1938), pp. 539-557.

— Polynomial approximations for elliptic functions. Read Dec. 30, 1937. Transactions of this Society, vol. 44, no. 1 (July, 1938), pp. 47-57.

- Lagrange and Wilson theorems for the generalized Stirling numbers. Read Nov. 27, 1937. Proceedings of the Edinburgh Mathematical Society, (2), vol. 5, no. 4 (Sept., 1938), pp. 171-173.

- Fifty years of algebra in America, 1888-1938. Read Sept. 7, 1938. American Mathematical Society Semicentennial Publications, vol. 2, 1938. pp. 1-34.

Bell, P. O. Covariant configurations related to analytic curved surfaces. Read June 18, 1936. Duke Mathematical Journal, vol. 4, no. 3 (Sept., 1938), pp. 590-599.

Berkeley, E. C. Boolean algebra (the technique for manipulating "and," "or," "not," and conditions) and applications to insurance. Read Sept. 1, 1936. Record of the American Institute of Actuaries, vol. 26, no. 54 (Oct., 1937), pp. 373-414.

Bernstein, B. A. Remark on Nicod's reduction of Principia Mathematica. Read April 3, 1937. Journal of Symbolic Logic, vol. 2, no. 4 (Dec., 1937), pp. 165-166.

- Postulates for abelian groups and fields in terms of non-associative operations. Read April 11, 1936. Transactions of this Society, vol. 43, no. 1 (Jan., 1938), pp. 1-6.

Bernstein, Felix. Regression and correlation evaluated by a method of partial sums. Read March 26, 1937. Annals of Mathematical Statistics, vol. 8, no. 2 (June, 1937), pp. 77-89.

Birkhoff, Garrett. On product integration. Read Feb. 23, 1935. Journal of Mathematics and Physics, Massachusetts Institute of Technology, vol. 16, no. 2 (Nov., 1937), pp. 104-132.

- Analytical groups. Read Dec. 31, 1936. Transactions of this Society, vol. 43, no. 1 (Jan., 1938), pp. 61-101.

—Dependent probabilities and spaces $(L)$. Read Feb. 26, 1938. Proceedings of the National Academy of Sciences, vol. 24, no. 3 (March, 1938), pp. 154-159.

- Lattices and their applications. Read April 15, 1938. This Bulletin, vol. 44, no. 12 (Dec., 1938), pp. 793-800.

Birkhoff, G. D. Fifty years of American mathematics. Read Sept. 7, 1938. American Mathematical Society Semicentennial Publications, vol. 2, 1938. pp. 270-315.

Blake, Archie. Canonical expressions in Boolean algebra. Read Oct. 29, 1932. Dissertation, Chicago, 1937.

Bliss, G. A. Normality and abnormality in the calculus of variations. Read April 20, 1935. Transactions of this Society, vol. 43, no. 3 (May, 1938), pp. 365-376.

—Definitely self-adjoint boundary value problems. Read April 11, 1936. Transactions of this Society, vol. 44, no. 3 (Nov., 1938), pp. 413-428.

Blumenthal, L. M. Metric foundation of hyperbolic geometry. Read Sept. 12, 1935. Revista de Ciencias, vol. 40, no. 423 (March, 1938), pp. 3-20.

Distance geometries. A study of the development of abstract metrics. Read Sept. 7, 1934, Feb. 23, 1935, Nov. 28, 1936, April 9 and Nov. 27, 1937. University of Missouri Studies, vol. 13, no. 2 (April, 1938). 145 pp.

Boas, R. P. Asymptotic relations for derivatives. Read Sept. 9, 1937. Duke Mathematical Journal, vol. 3, no. 4 (Dec., 1937), pp. 637-646.

Boas, R. P., and Bochner, Salomon. Closure theorems for translations. Read Feb. 26, 1938. Annals of Mathematics, (2), vol. 39, no. 2 (April, 1938), pp. 287-300. 
Bochner, Salomon. See Boas, R. P.

Brenner, Joel. The linear homogeneous group. Read Sept. 5 and Dec. 31, 1936. Annals of Mathematics, (2), vol. 39, no. 2 (April, 1938), pp. 472-493.

Bristow, Leonard. Expansion of functions in solutions of functional equations. Read Oct. 29, 1938. This Bulletin, vol. 44, no. 12 (Dec., 1938), pp. 874-879.

Browne, E. T. The classification of correlations in space. Read April 16, 1938. Journal of the Elisha Mitchell Scientific Society, vol. 54, no. 1 (June, 1938), pp. 23-44.

Burington, R. S. R-matrices and equivalent networks. I. Read Sept. 1, 1936. Journal of Mathematics and Physics, Massachusetts Institute of Technology, vol. 16, no. 2 (Nov., 1937), pp. 85-103.

Cairns, S. S. Normal coordinates for extremals transversal to a manifold. Read Sept. 10, 1937. American Journal of Mathematics, vol. 60, no. 2 (April, 1938), pp. 423-435.

Calkin, J. W. Abstract self-adjoint boundary conditions. Read Feb. 26, 1938. Proceedings of the National Academy of Sciences, vol. 24, no. 1 (Jan., 1938), pp. 38-42.

Cameron, R. H., and Martin, W. T. Analytic continuation of diagonals and Hadamard compositions of multiple power series. Read Dec. 29, 1936. Transactions of this Society, vol. 44, no. 1 (July, 1938), pp. 1-7.

Camp, C. C. Expansions involving differential equations in which the coefficient of a parameter changes sign. Read Nov. 28, 1936. National Mathematics Magazine, vol. 12, no. 5 (Feb., 1938), pp. 216-222.

- On multiparameter expansions associated with a differential system and auxiliary conditions at several points in each variable. Read Aug. 29, 1929. American Journal of Mathematics, vol. 60, no. 2 (April, 1938), pp. 447-452.

Carlitz, Leonard. A class of polynomials. Read Dec. 29, 1936. Transactions of this Society, vol. 43, no. 2 (March, 1938), pp. 167-182.

Chatland, Harold. The asymptotic Waring problem for homogeneous polynomial summands. Read April 9, 1937. Annals of Mathematics, (2), vol. 39, no. 1 (Jan., 1938), pp. 49-57.

Church, Alonzo. The constructive second number class. Read Dec. 29, 1937. This Bulletin, vol. 44, no. 4 (April, 1938), pp. 224-232.

Churchill, R. V. Additional notes on the inversion of the Laplace transformation. Read Nov. 27, 1937. Mathematische Zeitschrift, vol. 43, no. 5 (April, 1938), pp. 743748.

- The solution of linear boundary value problems in physics by means of the Laplace transformation. II. Temperatures in a composite wall. Read Sept. 10, 1937. Mathematische Annalen, vol. 115, no. 5 (June, 1938), pp. 720-739.

Cohen, L. W. Uniformity properties in topological space satisfying the first denumerability postulate. Read Nov. 30, 1935 and April 9, 1937. Duke Mathematical Journal, vol. 3, no. 4 (Dec., 1937), pp. 610-615.

Cohen, L. W., and Dunford, Nelson. Transformations on sequence spaces. Read Dec. 30 and 31, 1936. Duke Mathematical Journal, vol. 3, no. 4 (Dec., 1937), pp. 689-701.

Comenetz, George. Conformal geometry on a surface. Read Oct. 31, 1936. Annals of Mathematics, (2), vol. 39, no. 4 (Oct., 1938), pp. 863-871.

Coral, Max. On the necessary conditions for the minimum of a double integral. Read Aug. 31, 1932. Duke Mathematical Journal, vol. 3, no. 4 (Dec., 1937), pp. 585592.

- A generalization of a property of harmonic functions. Read Oct. 28, 1933. This Bulletin, vol. 44, no. 8 (Aug., 1938), pp. 587-592.

Courant, Richard. The existence of a minimal surface of least area bounded by 
prescribed Jordan arcs and prescribed surfaces. Read Feb. 26, 1938. Proceedings of the National Academy of Sciences, vol. 24, no. 2 (Feb., 1938), pp. 97-101.

Court, N. A. Sur la géométrie du tetraèdre. Read Dec. 31, 1936. Mathesis, vol. 51, nos. 5-7 (May-July, 1937), pp. 307-313.

Cramlet, C. M. Note on integrability conditions of implicit differential equations. Read Dec. 28, 1934. This Bulletin, vol. 44, no. 2 (Feb., 1938), pp. 107-109.

- Differential invariant theory of alternating tensors. Read Dec. 27, 1934. This Bulletin, vol. 44, no. 2 (Feb., 1938), pp. 110-114.

- On the reduction of a representation to classical canonical form. Read June 18, 1936. American Mathematical Monthly, vol.45, no. 3 (March, 1938), pp. 159-162.

Linear differential equations with constant coefficients. Read June 18, 1936. American Mathematical Monthly, vol. 45, no. 3 (March, 1938), pp. 162-165.

Daus, P. H. Collineations and central projections. Read Nov. 27, 1937. American Mathematical Monthly, vol. 45, no. 5 (May, 1938), pp. 294-298.

DeCicco, J. J. The geometry of whirl series. Read April 10, 1936. Transactions of this Society, vol. 43, no. 3 (May, 1938), pp. 344-358. See Kasner, Edward.

Dilworth, R. P. Abstract residuation over lattices. Read Nov. 27, 1937. This Bulletin, vol. 44, no. 4 (April, 1938), pp. 262-268.

Donahue, J. E. Concerning the geometry of the second derivative of a polygenic function. Read Feb. 22, 1930. Dissertation, Columbia, 1930.

Doob, J. L. Stochastic processes with an integral-valued parameter. Read April 9, 1937. Transactions of this Society, vol. 44, no. 1 (July, 1938), pp. 87-150.

Douglas, Jesse. The problem of Plateau. Read Oct. 29, 1938. Scripta Mathematica, vol. 5, no. 3 (July, 1938), pp. 159-164.

Dresch, F. W. Index numbers and the general economic equilibrium. Read April 3, 1937. This Bulletin, vol. 44, no. 2 (Feb., 1938), pp. 134-141.

Dresher, Melvin, and Ore, Oystein. Theory of multigroups. Read Feb. 26, 1938. American Journal of Mathematics, vol. 60, no. 3 (July, 1938), pp. 705-733.

Dressel, F. G. A note on Fredholm-Stieltjes integral equations. Read Dec. 29, 1936. This Bulletin, vol. 44, no. 6 (June, 1938), pp. 434-437.

Dribin, D. M. Normal extensions of quartic fields with the symmetric group. Read Feb. 20 and Sept. 7, 1937. Annals of Mathematics, (2), vol. 39, no. 2 (April, 1938), pp. 341-349.

Duffin, R. J. See Schaeffer, A. C.

Dunford, Nelson. On one parameter groups of linear transformations. Read Feb. 26, 1938. Annals of Mathematics, (2), vol. 39, no. 3 (July, 1938), pp. 569-573.

-Uniformity in linear spaces. Read Feb. 29 and Dec. 31, 1936. Transactions of this Society, vol. 44, no. 2 (Sept., 1938), pp. 305-356. See Cohen, L. W.

Evans, G. C. Dirichlet problems. Read Sept. 7, 1938. American Mathematical Society Semicentennial Publications, vol. 2, 1938. pp. 185-226.

Farrell, O. J. On the representation of bounded analytic functions by sequences of polynomials. Read Sept. 7, 1937. American Journal of Mathematics, vol. 60, no. 3 (July, 1938), pp. 573-576.

Feld, J. M. On certain groups of birational contact transformations. Read Feb. 26, 1938. This Bulletin, vol. 44, no. 8 (Aug., 1938), pp. 529-538.

Fialkow, Aaron. Geometric characterizations of invariant partial differential equations. Read Feb. 29, 1936 and March 27, 1937. American Journal of Mathematics, vol. 59, no. 4 (Oct., 1937), pp. 833-844. 
- Einstein spaces in a space of constant curvature. Read Oct. 30, 1937. Proceedings of the National Academy of Sciences, vol. 24, no. 1 (Jan., 1938), pp. 30-34.

The Riemannian curvature of a hypersurface. Read Sept. 10, 1937. This Bulletin, vol. 44, no. 4 (April, 1938), pp. 253-257.

Flood, M. M. Equivalence of pairs of matrices. Read March 27, 1937. Transactions of this Society, vol. 44, no. 1 (July, 1938), pp. 8-17.

Ford, L. R. Fractions. Read Nov. 28, 1936. American Mathematical Monthly, vol.45, no. 9 (Nov., 1938), pp. 586-601.

Foster, A. L. Natural systems. Read April 9, 1938. Proceedings of the National Academy of Sciences, vol. 24, no. 4 (April, 1938), pp. 185-187.

Frame, J. S. A symmetric representation of the twenty-seven lines on a cubic surface by lines in a finite geometry. Read Feb. 26, 1938. This Bulletin, vol. 44, no. 10 (Oct., 1938), pp. 658-661.

Frankel, L. R. See Hotelling, Harold.

Franklin, Philip. Note on the four color problem. Read Oct. 30, 1937. Journal of Mathematics and Physics, Massachusetts Institute of Technology, vol. 16, no. 4 (Jan., 1938), pp. 172-184.

Friedman, Bernard. Analyticity of equilibrium figures of rotation. Read Sept. 10, 1937. Transactions of this Society, vol. 43, no. 2 (March, 1938), pp. 183-198.

Frink, A. H., and Frink, Orrin. Polygonal variations. Read April 15, 1938. This Bulletin, vol. 44, no. 8 (Aug., 1938), pp. 539-547.

Frink, Orrin. See Frink, A. H.

Garabedian, H. L., and Randels, W. C. Theorems on Riesz means. Read April 9, 1938. Duke Mathematical Journal, vol. 4, no. 3 (Sept., 1938), pp. 529-533.

Ghent, K. S. Sums of values of a polynomial multiplied by constants. Read Nov. 30, 1934. Duke Mathematical Journal, vol. 3, no. 3 (Sept., 1937), pp. 518-528.

Glenn, O. E. Theory of planetary systems. Read Sept. 10, 1937. Annali della Reale Scuola Normale Superiore di Pisa, (2), vol. 7, nos. 3-4 (July, 1938), pp. 297-311.

Goldstine, H. H. The theorem of Hildebrandt. Read April 10, 1937. Studia Mathematica, vol. 7 (1937), pp. 157-158.

Weakly complete Banach spaces. Read Nov. 27,1937. Duke Mathematical Journal, vol. 4, no. 1 (March, 1938), pp. 125-131.

- A multiplier rule in abstract spaces. Read Sept. 10, 1937. This Bulletin, vol. 44, no. 6 (June, 1938), pp. 388-394.

Gore, G. D. Transformations of a surface bearing a family of asymptotic curves. Read Nov. 27, 1936. Transactions of this Society, vol. 43, no. 2 (March, 1938), pp. 303-320.

Green, J. W. A property of harmonic functions in three variables. Read Nov. 27, 1937. This Bulletin, vol. 44, no. 8 (Aug., 1938), pp. 548-557.

Green, Louis. Systems of quadrics associated with a point of a surface. Read April 9, 1937. American Journal of Mathematics, vol. 60, no. 3 (July, 1938), pp. 649-666.

Greenwood, J. A. Variance of a general matching problem. Read Sept. 10, 1937. Annals of Mathematical Statistics, vol. 9, no. 1 (March, 1938), pp. 56-59.

Griffiths, L. W. On hypergroups, multigroups, and product systems. Read Dec. 30, 1937. American Journal of Mathematics, vol. 60, no. 2 (April, 1938), pp. 345-354.

Hall, D. W., and Schweigert, G. E. Non-n-alternating transformations. Read Dec. 30, 1936. Duke Mathematical Journal, vol. 3, no. 4 (Dec., 1937), pp. 623-626.

Hall, Marshall. Group rings and extensions. I. Read March 27, 1937. Annals of Mathematics, (2), vol. 39 , no. 1 (Jan., 1938), pp. 220-234.

— An isomorphism between linear recurring sequences and algebraic rings. Read 
Dec. 31, 1935 and Sept. 3, 1936. Transactions of this Society, vol. 44, no. 2 (Sept., 1938), pp. 196-218.

Hall, N. A. Binary quadratic discriminants with a single class of forms in each genus. Read April 3, 1937. Mathematische Zeitschrift, vol. 44, no. 1 (June, 1938), pp. 85-90; Proceedings of the National Academy of Sciences, vol. 23, no. 7 (July, 1937), pp. 414-415.

Hall, Philip. On the system of normalizers of a soluble group. Read Sept. 5, 1936. Proceedings of the London Mathematical Society, (2), vol. 43, no. 7 (Dec., 1937), pp. 507-528.

Halmos, P. R. Note on almost-universal forms. Read Dec. 29, 1937. This Bulletin, vol. 44, no. 2 (Feb., 1938), pp. 141-144.

Halperin, Israel. On the transitivity of perspectivity in continuous geometries. Read Dec. 30, 1936. Transactions of this Society, vol. 44, no. 3 (Nov., 1938), pp. 537562.

Hamilton, H. J. Some theorems on subsequences. Read Nov. 27, 1937. This Bulletin, vol. 44, no. 4 (April, 1938), pp. 298-304.

- Change of dimension in sequence transformations. Read April 16, 1938. Duke Mathematical Journal, vol. 4, no. 2 (June, 1938), pp. 341-342.

- A generalization of multiple sequence transformations. Read April 16, 1938. Duke Mathematical Journal, vol. 4, no. 2 (June, 1938), pp. 342-358.

Hamilton, O. H. Fixed points under transformations of continua which are not connected im kleinen. Read Sept. 10, 1937. Transactions of this Society, vol. 44, no. 1 (July, 1938), pp. 18-24.

- Non-unqiue solutions of systems of first order ordinary differential equations. Read Jan. 2, 1936. Annals of Mathematics, (2), vol. 39, no. 4 (Oct., 1938), pp. 786-793.

Hartman, Philip, and Kershner, R. B. On the Fourier-Stieltjes transform of a singular function. Read Feb. 26, 1938. American Journal of Mathematics, vol. 60, no. 2 (April, 1938), pp. 459-462.

Haviland, E. K. On an asymptotic expression for a certain integral. Read Feb. 29, 1936. Quarterly Journal of Mathematics, vol. 7, no. 26 (June, 1936), pp. 152-157.

Hedlund, G. A. See Morse, Marston.

Hille, Einar. The inversion problem of Möbius. Read March 27, 1937. Duke Mathematical Journal, vol. 3, no. 4 (Dec., 1937), pp. 549-568.

- On semi-groups of transformations in Hilbert space. Read Feb. 26, 1938. Proceedings of the National Academy of Sciences, vol. 24, no. 3 (March, 1938), pp. 159-161.

- On the absolute convergence of polynomial series. Read Feb. 26, 1938. American Mathematical Monthly, vol. 45, no. 4 (April, 1938), pp. 220-226.

- Bilinear formulas in the theory of the transformations of Laplace. Read Nov. 28, 1936. Compositio Mathematica, vol. 6, no. 1 (Aug., 1938), pp. 93-102.

Hoel, P. G. A significance test for component analysis. Read April 10, 1937. Annals of Mathematical Statistics, vol. 8, no. 3 (Sept., 1937), pp. 149-158.

- On the chi-square distribution for small samples. Read April 9, 1938. Annals of Mathematical Statistics, vol. 9, no. 3 (Sept., 1938), pp. 158-165.

Hollcroft, T. R. Singularities and contacts in a linear system and its linear sub-systems. Read Sept. 7, 1934 and April 10, 1936. Rendiconti del Circolo Matematico di Palermo, vol. 61, no. 2 (May-Aug., 1937), pp. 111-122.

Hopkins, Charles. The half-group of cosets belonging to a group. Read April 16, 1938. Duke Mathematical Journal, vol. 4, no. 1 (March, 1938), pp. 30-38.

Hotelling, Harold, and Frankel, L. R. The transformation of statistics to simplify their 
distribution. Read Dec. 30, 1937. Annals of Mathematical Statistics, vol. 9, no. 2 (June, 1938), pp. 87-96.

Hull, Ralph. See Nowlan, F. S.

Huntington, E. V. A rating table for card-matching experiments. Read Dec. 30, 1937. Journal of Parapsychology, Duke University, vol. 1, no. 4 (Dec., 1937), pp. 292-294.

Hurd, C. C. Asymptotic theory of linear differential equations singular in the variable of differentiation and in a parameter. Read Dec. 29, 1936. Tôhoku Mathematical Journal, vol. 44, no. 2 (March, 1938), pp. 243-274.

Hyers, D. H. On functional equations in linear topological spaces. Read Sept. 10, 1937. Proceedings of the National Academy of Sciences, vol. 23, no. 9 (Sept., 1937), pp. 496-499.

- A note on linear topological spaces. Read April 3, 1937. This Bulletin, vol. 44, no. 2 (Feb., 1938), pp. 76-80.

See Michal, A. D.

Ingraham, M. H. On certain equations in matrices whose elements belong to a division algebra. Read Sept. 8, 1937. This Bulletin, vol. 44, no. 2 (Feb., 1938), pp. 117124.

Ingraham, M. H., and Wolf, M. C. Convergence of a sequence of linear transformations. Read April 9, 1937. American Journal of Mathematics, vol. 60, no. 1 (Jan., 1938), pp. 107-119.

Ingram, W. H. Kirchhoff constraints and sagittal graphs. Read Feb. 26, 1938. Philosophical Magazine, (7), vol. 26, no. 174 (Aug., 1938), pp. 268-271.

Jackson, Dunham. Problems of closest approximation on a two-dimensional region. Read Dec. 31, 1936. American Journal of Mathematics, vol. 60, no. 2 (April, 1938), pp. 436-446.

- Orthogonal polynomials in two complex variables. Read Sept. 8, 1937. Annals of Mathematics, (2), vol. 39, no. 2 (April, 1938), pp. 262-268.

- Orthogonal polynomials in three variables. Read Dec. 31, 1936 and Nov. 27, 1937. Duke Mathematical Journal, vol. 4, no. 3 (Sept., 1938), pp. 441-454.

Jacobson, Nathan. Simple Lie algebras of type A. Read March 27, 1937. Annals of Mathematics, (2), vol. 39, no. 1 (Jan., 1938), pp. 181-188.

- Simple Lie algebras over a field of characteristic zero. Read April 16, 1938. Duke Mathematical Journal, vol. 4, no. 3 (Sept., 1938), pp. 534-551.

James, Glenn. A higher upper limit to the parameters in Fermat's equation. Read Nov. 28, 1936 and Nov. 27, 1937. American Mathematical Monthly, vol. 45, no. 7 (Aug.-Sept., 1938), pp. 439-445.

James, R. D. A problem in additive number theory. Read Nov. 28, 1936 and April 3, 1937. Transactions of this Society, vol. 43, no. 2 (March, 1938), pp. 296-302.

- On a diophantine equation of the fourth degree. Read Dec. 1, 1934. Proceedings of the London Mathematical Society, (2), vol. 44, no. 2 (April, 1938), pp. 140148.

The distribution of integers represented by quadratic forms. Read April 9, 1938. American Journal of Mathematics, vol. 60, no. 3 (July, 1938), pp. 737-744.

Jeffery, R. L. The equivalence of sequence integrals and non-absolutely convergent integrals. Read Jan. 1, 1936. This Bulletin, vol. 44, no. 12 (Dec., 1938), pp. 840845.

John, Fritz. The ultrahyperbolic differential equation with four independent variables. Read Sept. 10, 1937. Duke Mathematical Journal, vol. 4, no. 2 (June, 1938), pp. 300-322. 
Jones, F. B. Concerning R. L. Moore's Axiom 5. Read April 9, 1938. This Bulletin, vol. 44, no. 10 (Oct., 1938), pp. 689-692.

Jordan, J. Q., and Leighton, Walter. On the permutation of the convergents of a continued fraction and related convergence criteria. Read Sept. 1, 1936. Annals of Mathematics, (2), vol. 39, no. 4 (Oct., 1938), pp. 872-882.

Kagno, I. N. Perfect subdivision of surfaces. Read April 16, 1938. Journal of Mathematics and Physics, Massachusetts Institute of Technology, vol. 17, no. 2 (June, 1938), pp. 76-111.

van Kampen, E. R. Remarks on systems of ordinary differential equations. Read April 11, 1936. American Journal of Mathematics, vol. 59, no. 1 (Jan., 1937), pp. 144152.

van Kampen, E. R., and Wintner, Aurel. On the reduction of dynamical systems by means of parametrized invariant relations. Read April 16, 1938. Transactions of this Society, vol. 44, no. 2 (Sept., 1938), pp. 168-195.

Kasner, Edward. Characterization of the conformal group and the equi-long group by horn angles. Read Feb. 26, 1927. Duke Mathematical Journal, vol. 4, no. 1 (March, 1938), pp. 95-106.

The two conformal invariants of fifth order. Read Sept. 10, 1937. Transactions of this Society, vol. 44, no. 1 (July, 1938), pp. 25-31.

- Polygenic functions whose associated element-to-point transformation converts unions into points. Read Sept. 6, 1938. This Bulletin, vol. 44, no. 10 (Oct., 1938), pp. 726-732.

Kasner, Edward, and DeCicco, J. J. Classification of element transformations by means of isogonal and equi-tangential series. Read Dec. 30, 1937. Proceedings of the National Academy of Sciences, vol. 24, no. 1 (Jan., 1938), pp. 34-38.

- The geometry of the whirl-motion group $G_{6}$ : elementary invariants. Read Dec. 30, 1937. This Bulletin, vol. 44, no. 6 (June, 1938), pp. 399-403.

Kawaguchi, Akitsugu. Geometry in an n-dimensional space with the arc length $s=\int\left\{A_{i}\left(x, x^{\prime}\right) x^{\prime \prime i}+B\left(x, x^{\prime}\right)\right\}^{1 / p} d t$. Read Dec. 30, 1937. Transactions of this Society, vol. 44, no. 2 (Sept., 1938), pp. 153-167.

Kershner, R. B. Determination of a van der Corput absolute constant. Read Nov. 26, 1937. American Journal of Mathematics, vol. 60 , no. 3 (July, 1938), pp. 549554.

- See Hartman, Philip.

Ketchum, G. S., and Ketchum, P. W. On a certain class of non-linear expansions of an arbitrary analytic function. Read Sept. 9, 1937. Annals of Mathematics, (2), vol. 39 , no. 1 (Jan., 1938), pp. 58-64.

Ketchum, P. W. See Ketchum, G. S.

Kimball, W. S. Differentiation of line integrals by parallel displacement. Read Nov. 28, 1936. Philosophical Magazine, (7), vol. 25, no. 166 (Jan., 1938), pp. 1-45.

- Application of derivatives of line integrals. Read April 9, 1937. Philosophical Magazine, (7), vol. 35, no. 168 (March, 1938), pp. 549-567.

Klipple, E. C. Two-dimensional spaces in which there exist contiguous points. Read Oct. 28, 1933. Transactions of this Society, vol. 44, no. 2 (Sept., 1938), pp. 250276.

Knebelman, M. S. Contact transformations. Read April 16, 1938. Annals of Mathematics, (2), vol. 39, no. 3 (July, 1938), pp. 507-515.

Kraus, C. A. The present status of the theory of electrolytes. Read Dec. 28, 1937. This Bulletin, vol. 44, no. 6 (June, 1938), pp. 361-383.

Kullback, Solomon. On certain distributions derived from the multinomial distribution. 
Read Nov. 30, 1935 and Jan. 2, 1936. Annals of Mathematical Statistics, vol. 8, no. 3 (Sept., 1937), pp. 127-144.

Lane, E. P., and MacQueen, M. L. Asymptotic curves on a surface. Read April 10, 1937. American Journal of Mathematics, vol. 60, no. 3 (July, 1938), pp. 640648.

Lehmer, D. H. On the Hardy-Ramanujan series for the partition function. Read Feb. 20, 1937. Journal of the London Mathematical Society, vol. 12, no. 3 (July, 1937), pp. 171-176.

- An application of Schläfli's modular equation to a conjecture of Ramanujan. Read Sept. 10, 1937. This Bulletin, vol. 44, no. 2 (Feb., 1938), pp. 84-90.

- On the series for the partition function. Read March 27, 1937. Transactions of this Society, vol. 43, no. 2 (March, 1938), pp. 271-295.

- A cotangent analogue of continued fractions. Read Feb. 26, 1938. Duke Mathematical Journal, vol. 4, no. 2 (June, 1938), pp. 323-340.

Leighton, Walter. See Jordan, J. Q.

Lester, C. A. A determination of the automorphisms of certain algebraic fields. Read Oct. 30, 1937. Duke Mathematical Journal, vol. 4, no. 2 (June, 1938), pp. 277290.

Levinson, Norman. On the growth of analytic functions. Read Sept. 10, 1937. Transactions of this Society, vol. 43, no. 2 (March, 1938), pp. 240-257.

Lewis, D. C. Invariant manifolds near an invariant point of unstable type. Read Sept. 10, 1937. American Journal of Mathematics, vol. 60, no. 3 (July, 1938), pp. 577587.

Lewy, Hans. On differential geometry in the large. I (Minkowski's problem). Read Nov. 28, 1936. Transactions of this Society, vol. 43, no. 2 (March, 1938), pp. 258-270.

- Generalized integrals and differential equations. Read Nov. 28, 1936. Transactions of this Society, vol. 43, no. 3 (May, 1938), pp. 437-464.

- A property of spherical harmonics. Read April 9, 1938. American Journal of Mathematics, vol. 60, no. 3 (July, 1938), pp. 555-560.

Lowan, A. N. On the operational determination of two dimensional Green's functions in the theory of heat conduction. Read Oct. 30, 1937. This Bulletin, vol. 44, no. 2 (Feb., 1938), pp. 125-133.

Lubben, R. G. Concerning limiting sets in abstract spaces. II. Read Dec. 27, 1928, Aug. 30, 1929 and Sept. 9, 1931. Transactions of this Society, vol. 43, no. 3 (May, 1938), pp. 482-493.

Lubin, C. I. Transformation of differential equations in the neighborhood of singular points. Read Sept. 12, 1930. Duke Mathematical Journal, vol. 3, no. 3 (Sept., 1937), pp. 394-417.

McCoy, N. H. Subrings of direct sums. Read Sept. 10, 1937. American Journal of Mathematics, vol. 60, no. 2 (April, 1938), pp. 374-382.

- Subrings of infinite direct sums. Read Dec. 30, 1937. Duke Mathematical Journal, vol. 4, no. 3 (Sept., 1938), pp. 486-494.

McEwen, W. H. A note on an extension of Bernstein's theorem. Read Sept. 10, 1937. American Journal of Mathematics, vol. 60, no. 2 (April, 1938), pp. 309-319.

McShane, E. J. Some existence theorems for problems in the calculus of variations. Read April 10, 1937. Duke Mathematical Journal, vol. 4, no. 1 (March, 1938), pp. 132-156.

Some existence theorems in the calculus of variations. I. The Dresden corner condition. Read Dec. 28, 1937. Transactions of this Society, vol. 44, no. 3 (Nov., 1938), pp. $429-438$. 
- Some existence theorems in the calculus of variations. II. Existence theorems for isoperimetric problems in the plane. Read Dec. 28, 1937 and April 15, 1938. Transactions of this Society, vol. 44, no. 3 (Nov., 1938), pp. 439-453.

Recent developments in the calculus of variations. Read Sept. 8, 1938. American Mathematical Society Semicentennial Publications, vol. 2, 1938. pp. 69-97.

MacLane, Saunders. A lattice formulation for transcendence degrees and p-bases. Read April 9, 1938. Duke Mathematical Journal, vol. 4, no. 3 (Sept., 1938), pp. 455468.

- The Schönemann-Eisenstein irreducibility criteria in terms of prime ideals. Read Jan. 2, 1936. Transactions of this Society, vol. 43, no. 2 (March, 1938), pp. 226239.

- The uniqueness of the power series representation of certain fields with valuations. Read Dec. 29, 1937. Annals of Mathematics, (2), vol. 39, no. 2 (April, 1938), pp. 370-382.

MacLane, Saunders, and Adkisson, V. W. Fixed points and the extension of the homeomorphisms of a planar graph. Read March 27, 1937. American Journal of Mathematics, vol. 60, no. 3 (July, 1938), pp. 611-639.

MacNeille, H. M. The application of lattice theory to integration. Read April 15, 1938. This Bulletin, vol. 44, no. 12 (Dec., 1938), pp. 825-827.

MacQueen, M. L. See Lane, E. P.

Maddaus, Ingo. On completely continuous linear transformations. Read Sept. 10, 1937. This Bulletin, vol. 44, no. 4 (April, 1938), pp. 279-282.

Madow, W. G. Contributions to the theory of comparative statistical analysis. I. Fundamental theorems of comparative analysis. Read March 27, 1937. Annals of Mathematical Statistics, vol. 8, no. 3 (Sept., 1937), pp. 159-176.

- Contributions to the theory of multivariate statistical analysis. Read March 26, 1937. Transactions of this Society, vol. 44, no. 3 (Nov., 1938), pp. 454-495.

Mancill, J. D. On volumes bounded by cylindrical surfaces. Read April 9, 1938. American Mathematical Monthly, vol. 45, no. 2 (Feb., 1938), pp. 109-111.

Martin, W. T. Linear difference equations with arbitrary real spans. Read Feb. 23, 1935. Acta Mathematica, vol. 69 (1938), pp. 57-98.

- See Cameron, R. H.; Wiener, Norbert.

Mehlenbacher, L. E. The interrelations of the fundamental solutions of the hypergeometric equation; logarithmic case. Read April 10, 1936. American Journal of Mathematics, vol. 60, no. 1 (Jan., 1938), pp. 120-128; dissertation, Michigan, 1936.

Menger, Karl. Über die Dimension von Punktmengen. III. Zur Begründung einer axiomatischen Theorie der Dimension. Read Dec. 31, 1930. Monatshefte für Mathematik und Physik, vol. 36 (1929), pp. 193-218.

— Nouvelle démonstration de l'équation d'Euler-Lagrange. Read March 26, 1937. Paris Comptes Rendus, vol. 204, no. 12 (March, 1937), pp. 948-951.

- An abstract form of the covering theorems of topology. Read Dec. 29, 1937. Annals of Mathematics, (2), vol. 39, no. 4 (Oct., 1938), pp. 794-803.

- Non-euclidean geometry of joining and intersecting. Read April 15, 1938. This Bulletin, vol. 44, no. 12 (Dec., 1938), pp. 821-824.

Merriman, G. M. Concerning sets of polynomials orthogonal simultaneously on several circles. Read Sept. 1, 1936. This Bulletin, vol. 44, no. 2 (Feb., 1938), pp. 57-69.

Mersman, W. A. A new summation method for divergent series. Read April 11, 1936. This Bulletin, vol. 44, no. 10 (Oct., 1938), pp. 667-673.

Michal, A. D., and Hyers, D. H. Differential invariants in a general differential geome- 
try. Read Nov. 28, 1936. Proceedings of the National Academy of Sciences, vol. 23, no. 11 (Nov., 1937), pp. 590-593.

Theory and applications of abstract normal coordinates in a general differential geometry. Read Sept. 5, 1936. Annali della Reale Scuola Normale Superiore di Pisa, (2), vol. 7, no. 2 (April, 1938), pp. 157-175.

Milgram, A. N. Decompositions and dimension of closed sets in $R^{n}$. Read March 27, 1937. Transactions of this Society, vol. 43, no. 3 (May, 1938), pp. 465-481.

- A general existence theorem and some applications. Read Dec. 28, 1937. Annals of Mathematics, (2), vol. 39, no. 4 (Oct., 1938), pp. 804-810.

Miller, E. W. On a property of families of sets. Read April 11, 1936. Comptes Rendus des Séances de la Société des Sciences et des Lettres de Varsovie, Classe III, vol. 30 (1937), pp. 31-38.

Montgomery, Deane, and Zippin, Leo. Compact abelian transformation groups. Read Oct. 30, 1937. Duke Mathematical Journal, vol. 4, no. 2 (June, 1938), pp. 363373.

Moore, C. N. Summable Series and Convergence Factors. Read Dec. 2, 1933, Feb. 23, 1935 and Jan. 1, Sept. 3 and Dec. 31, 1936. American Mathematical Society Colloquium Publications, vol. 22, 1938. 105 pp.

Morrey, C. B. On the solutions of quasi-linear elliptic partial differential equations. Read June 20 and Dec. 1, 1934 and April 11, 1936. Transactions of this Society, vol. 43, no. 1 (Jan., 1938), pp. 126-166.

Morse, A. P. A continuous function with no unilateral derivatives. Read Dec. 30, 1937. Transactions of this Society, vol. 44, no. 3 (Nov., 1938), pp. 496-507. See Agnew, R. P.

Morse, Marston, and Hedlund, G. A. Symbolic dynamics. Read Dec. 28, 1934 and April 15, 1938. American Journal of Mathematics, vol. 60, no. 4 (Oct., 1938), pp. 815-866.

Myers, S. B. Arclength in metric and Finsler manifolds. Read April 9, 1937. Annals of Mathematics, (2), vol. 39, no. 2 (April, 1938), pp. 463-471.

Nakayama, Tadasi. A remark on representations of groups. Read Oct. 30, 1937. This Bulletin, vol. 44, no. 4 (April, 1938), pp. 233-235.

- A note on the elementary divisor theory in non-commutative domains. Read Feb. 26, 1938. This Bulletin, vol. 44, no. 10 (Oct., 1938), pp. 719-723.

Nakayama, Tadasi, and Nesbitt, C. J. Note on symmetric algebras. Read April 16, 1938. Annals of Mathematics, (2), vol. 39, no. 3 (July, 1938), pp. 659-668.

Nesbitt, C. J. See Nakayama, Tadasi.

Newsom, C. V. On the character of certain entire functions in distant portions of the plane. Read Sept. 9, 1931. American Journal of Mathematics, vol. 60, no. 3 (July, 1938), pp. 561-572.

Nowlan, F. S., and Hull, Ralph. Sets of integral elements of certain rational division algebras. First paper. Read April 18, 1930. Transactions of the Royal Society of Canada, (3), Section III, vol. 31 (1937), pp. 163-184.

Oldenburger, Rufus. Relations between ranks of a general matrix. Read April 11, 1936. Annals of Mathematics, (2), vol. 39, no. 1 (Jan., 1938), pp. 172-177.

- Representation and equivalence of forms. Read April 16, 1938. Proceedings of the National Academy of Sciences, vol. 24, no. 4 (April, 1938), pp. 193-198.

- Rational equivalence of a form to a sum of pth powers. Read April 10, 1936 and April 9, 1937. Transactions of this Society, vol. 44, no. 2 (Sept., 1938), pp. 219-249.

Olds, E. G. Distributions of sums of squares of rank differences for small numbers of 
individuals. Read Dec. 29, 1936. Annals of Mathematical Statistics, vol. 9, no. 2 (June, 1938), pp. 133-148.

A moment-generating function which is useful in solving certain matching problems. Read Dec. 30, 1937. This Bulletin, vol. 44, no. 6 (June, 1938), pp. 407-413.

Olshen, A. C. Transformations of the Pearson type III distribution. Read April 9, 1937. Annals of Mathematical Statistics, vol. 9, no. 3 (Sept., 1938), pp. 176-200.

Ore, Oystein. On functions with bounded derivatives. Read March 26, 1937. Transactions of this Society, vol. 43, no. 2 (March, 1938), pp. 321-326.

- On the application of structure theory to groups. Read April 15, 1938. This Bulletin, vol. 44, no. 12 (Dec., 1938), pp. 801-806.

See Dresher, Melvin.

Perlin, I. E. Sufficient conditions for a minimum in the problem of Lagrange with isoperimetric conditions. Read Oct. 26, 1935. Contributions to the Calculus of Variations, 1933-1937, University of Chicago. pp. 207-241.

Peterson, T. S. The analogue of Weyl's conformal curvature tensor in a Michal functional geometry. Read March 18, 1933. Annali di Matematica, (4), vol. 13 (1935), pp. $55-62$.

Pettis, B. J. A note on regular Banach spaces. Read Oct. 30, 1937. This Bulletin, vol. 44 , no. 6 (June, 1938), pp. 420-428.

Linear functionals and completely additive set functions. Read Feb. 26, 1938. Duke Mathematical Journal, vol. 4, no. 3 (Sept., 1938), pp. 552-565.

On integration in vector spaces. Read March 27, 1937. Transactions of this Society, vol. 44, no. 2 (Sept., 1938), pp. 277-304.

Pitcher, A. E., and Sewell, W. E. Existence theorems for solutions of differential equations of non-integral order. Read Sept. 10, 1937. This Bulletin, vol. 44, no. 2 (Feb., 1938), pp. 100-107.

Poritsky, Hillel. Green's formulas for analytic functions. Read Dec. 27, 1928. Annals of Mathematics, (2), vol. 39, no. 1 (Jan., 1938), pp. 31-48.

- Generalizations of the Gauss law of the spherical mean. Read Dec. 27, 1928. Transactions of this Society, vol. 43, no. 2 (March, 1938), pp. 199-225.

Puckett, W. T. A theorem concerning homologies in a compact space. Read March 27, 1937. Fundamenta Mathematicae, vol. 31 (1938), pp. 22-26.

Randels, W. C. On an approximate functional equation of Paley. Read Feb. 23, 1935. Transactions of this Society, vol. 43, no. 1 (Jan., 1938), pp. 102-125.

- On the order of the partial sums of a Fourier series. Read April 10, 1937. This Bulletin, vol. 44, no. 4 (April, 1938), pp. 286-288.

On the absolute summability of Fourier series. Read Dec. 30, 1937. This Bulletin, vol. 44, no. 10 (Oct., 1938), pp. 733-736.

- See Garabedian, H. L.

Reid, W. T. An integro-differential boundary value problem. Read Dec. 28, 1934 and April 19, 1935. American Journal of Mathematics, vol. 60, no. 2 (April, 1938), pp. 257-292.

- A theorem on quadratic forms. Read Dec. 30, 1937. This Bulletin, vol. 44, no. 6 (June, 1938), pp. 437-440.

- A system of ordinary linear differential equations with two-point boundary conditions. Read April 11, 1936. Transactions of this Society, vol. 44, no. 3 (Nov., 1938), pp. 508-521.

Richardson, Moses. Special homology groups. Read Sept. 9, 1937. Proceedings of the National Academy of Sciences, vol. 24, no. 1 (Jan., 1938), pp. 21-23.

Richardson, Moses, and Smith, P. A. Periodic transformations of complexes. Read 
Sept. 9, 1937. Annals of Mathematics, (2), vol. 39, no. 3 (July, 1938), pp. 611633.

Risselman, W. C. Approximation to a given function by means of polynomials in another given function. Read April 7, 1928. This Bulletin, vol. 44, no. 4 (April, 1938), pp. 241-249.

Ritt, J. F. On certain points in the theory of algebraic differential equations. Read Sept. 10, 1937. American Journal of Mathematics, vol. 60, no. 1 (Jan., 1938), pp. 1-43.

- Systems of differential equations. I. Theory of ideals. Read April 16, 1938. American Journal of Mathematics, vol. 60, no. 3 (July, 1938), pp. 535-548.

- Algebraic aspects of the theory of differential equations. Read Sept. 8, 1938. American Mathematical Society Semicentennial Publications, vol. 2, 1938. pp. 35-55.

Roberts, J. H., and Steenrod, N. E. Monotone transformations of two-dimensional manifolds. Read April 15, 1938. Annals of Mathematics, (2), vol. 39, no. 4 (Oct., 1938), pp. 851-862.

Robertson, M. S. Multivalent functions of order p. Read Feb. 20, 1937. This Bulletin, vol. 44, no. 4 (April, 1938), pp. 282-285.

Robinson, L. B. A quasi analytic function which satisfies a functional equation. Read Sept. 10, 1937. Revista de Ciencias, vol. 39, no. 422 (Dec., 1937), pp. 139-151.

Robinson, R. M. Note on convex regions on the sphere. Read Nov. 27, 1937. This Bulletin, vol. 44, no. 2 (Feb., 1938), pp. 115-116.

Rosenbaum, Benjamin. Divisibility of generalized factorials. Read April 10, 1936. This Bulletin, vol. 44, no. 8 (Aug., 1938), pp. 566-572.

Rosser, Barkley, and Walker, R. J. On the transformation groupfor diabolicmagic squares of order four. Read Dec. 30, 1937. This Bulletin, vol. 44, no. 6 (June, 1938), pp. 416-420.

Schaeffer, A. C., and Duffin, R. J. On some inequalities of S. Bernstein and W. Markoff for derivatives of polynomials. Read April 8, 1938. This Bulletin, vol. 44, no. 4 (April, 1938), pp. 289-297.

Schilling, O. F. G. The structure of local class field theory. Read Dec. 30, 1937. American Journal of Mathematics, vol. 60, no. 1 (Jan., 1938), pp. 75-100.

- A generalization of local class field theory. Read Dec. 30, 1937 and April 16, 1938. American Journal of Mathematics, vol. 60, no. 3 (July, 1938), pp. 667-704.

Schoenberg, I. J. On the Peano curve of Lebesgue. Read April 16, 1938. This Bulletin, vol. 44, no. 8 (Aug., 1938), p. 519.

Metric spaces and completely monotone functions. Read April 16, 1938. Annals of Mathematics, (2), vol. 39, no. 4 (Oct., 1938), pp. 811-841.

Metric spaces and positive definite functions. Read Dec. 29, 1937. Transactions of this Society, vol. 44, no. 3 (Nov., 1938), pp. 522-536.

Schweigert, G. E. See Hall, D. W.

Sewell, W. E. Degree of approximation by polynomials-problem $\alpha$. Read Dec. 31, 1936. Proceedings of the National Academy of Sciences, vol. 23, no. 9 (Sept., 1937), pp. 491-493.

- Note on the Faber coefficients of a continuous function. Read Dec. 30, 1937. Revista de Ciencias, vol. 39, no. 421 (Sept., 1937), pp. 79-82.

The derivative of a polynomial on various arcs of the complex domain. Read Sept. 10, 1937. National Mathematics Magazine, vol. 12, no. 4 (Jan., 1938), pp. 167170.

Note on the relation between Lipschitz conditions and degree of polynomial approximation. Read April 16, 1938. Tôhoku Mathematical Journal, vol. 44, no. 2 (March, 1938), pp. 347-350. 
—Degree of approximation by polynomials in z and 1/z. Read April 16, 1938. Duke Mathematical Journal, vol. 4, no. 2 (June, 1938), pp. 393-400.

See Pitcher, A. E.; Walsh, J. L.

Sheffer, I. M. Concerning Appell sets and associated linear functional equations. Read March 26, 1937. Duke Mathematical Journal, vol. 3, no. 4 (Dec., 1937), pp. 593-609.

Shiffman, Max. The Plateau problem for minimal surfaces which are relative minima. Read March 26, 1937. Annals of Mathematics, (2), vol. 39, no. 2 (April, 1938), pp. 309-315.

Shohat, J. A. Sur les polynomes orthogonaux généralisés. Read Oct. 29, 1938. Paris Comptes Rendus, vol. 207, no. 14 (Oct., 1938), pp. 556-558.

Simond, R. G. Relations between certain continuous transformations of sets. Read April 9, 1937. Duke Mathematical Journal, vol. 4, no. 3 (Sept., 1938), pp. 575-589.

Singer, James. A theorem in finite projective geometry and some applications to number theory. Read Oct. 27, 1934. Transactions of this Society, vol. 43, no. 3 (May, 1938), pp. 377-385.

Sinkov, Abraham. On generating the simple group $L F\left(2,2^{N}\right)$ by two operators of periods two and three. Read Feb. 20, 1937. This Bulletin, vol. 44, no. 6 (June, 1938), pp. $449-455$.

Smith, F. C. Relations among the fundamental solutions of the generalized hypergeometric equation when $p=q+1$. I. Non-logarithmic cases. Read Dec. 30, 1937. This Bulletin, vol. 44, no. 6 (June, 1938), pp. 429-433.

Smith, P. A. The topology of transformation groups. Read Feb. 26, 1938. This Bulletin, vol. 44, no. 8 (Aug., 1938), pp. 497-514. See Richardson, Moses.

Sokolnikoff, E. S. See Sokolnikoff, I. S.

Sokolnikoff, I. S., and Sokolnikoff, E. S. Torsion of regions bounded by circular arcs. Read Dec. 30, 1937. This Bulletin, vol. 44, no. 6 (June, 1938), pp. 384-387.

Spencer, V. E. Asymptotic expressions for the zeros of generalized Laguerre polynomials and Weber functions. Read Oct. 26, 1935. Duke Mathematical Journal, vol. 3, no. 4 (Dec., 1937), pp. 667-675.

Starkey, D. M. A test of the significance of the difference between means of samples from two normal populations without assuming equal variances. Read Dec. 30, 1937. Annals of Mathematical Statistics, vol. 9, no. 3 (Sept., 1938), pp. 201-213.

Steenrod, N. E. See Roberts, J. H.

Stone, M. H. The representation of Boolean algebras. Read April 15, 1938. This Bulletin, vol. 44, no. 12 (Dec., 1938), pp. 807-816.

Synge, J. L. The absolute optical instrument. Read March 27, 1937. Transactions of this Society, vol. 44, no. 1 (July, 1938), pp. 32-46.

- Hydrodynamical stability. Read Sept. 8, 1938. American Mathematical Society Semicentennial Publications, vol. 2, 1938. pp. 227-269.

Szász, Otto. The jump of a function determined by its Fourier coefficients. Read Feb. 26, 1938. Duke Mathematical Journal, vol. 4, no. 2 (June, 1938), pp. 401-407.

- On Fourier series with restricted coefficients. Read April 9, 1938. This Bulletin, vol. 44, no. 12 (Dec., 1938), pp. 850-859.

Taub, A. H. Spin representation of inversions. Read Sept. 9, 1937. This Bulletin, vol. 44, no. 12 (Dec., 1938), pp. 860-864.

Taylor, A. E. On the properties of analytic functions in abstract spaces. Read Nov. 28, 1936. Mathematische Annalen, vol. 115, no. 3 (March, 1938), pp. 466-484.

- Biharmonic functions in abstract spaces. Read April 3, 1937. American Journal of Mathematics, vol. 60, no. 2 (April, 1938), pp. 416-422. 
_Linear operations which depend analytically on a parameter. Read Feb. 26, 1938. Annals of Mathematics, (2), vol. 39, no. 3 (July, 1938), pp. 574-593.

Teach, V. B. The Hamilton-Jacobi theory for the problem of Lagrange in parametric form. Read Nov. 30, 1929. Contributions to the Calculus of Variations, 19331937, University of Chicago. pp. 165-206.

Thomas, T. Y. Recent trends in geometry. Read Sept. 9, 1938. American Mathematical Society Semicentennial Publications, vol. 2, 1938. pp. 98-135.

Thrall, R. M. Metabelian groups and trilinear forms. Read April 9, 1937. American Journal of Mathematics, vol. 60, no. 2 (April, 1938), pp. 383-415.

- Apolarity of trilinear forms and pencils of bilinear forms. Read April 8, 1938. This Bulletin, vol. 44, no. 10 (Oct., 1938), pp. 678-683.

Thurston, H. S. Matric conjugates in a ring $R(A)$. Read Dec. 28, 1937. This Bulletin, vol. 44, no. 4 (April, 1938), pp. 258-261.

Titt, E. W. (n-1)-dimensional characteristic strips of a first order equation and Cauchy's problem. Read Feb. 23, 1935. Duke Mathematical Journal, vol. 3, no. 4 (Dec., 1937), pp. 740-746.

Tornheim, Leonard. Sums of $n$-th powers in fields of prime characteristic. Read April 9, 1938. Duke Mathematical Journal, vol. 4, no. 2 (June, 1938), pp. 359-362.

Torrance, E. M. Superposition of functions on monotonic functions. Read Sept. 10, 1937. Fundamenta Mathematicae, vol. 30 (1938), pp. 90-91.

Trjitzinsky, W. J. Linear difference equations containing a parameter. Read April 11, 1936. Annali di Matematica, (4), vol. 14, nos. 3-4 (July, 1935-Jan., 1936), pp. 181-214.

- Singular point problems in the theory of linear differential equations. Read Nov. 26, 1937. This Bulletin, vol. 44, no. 4 (April, 1938), pp. 209-223.

— Théorie des fonctions d'une variable complexes définies sur des ensembles généraux. Read Dec. 28, 1937. Annales Scientifiques de l'École Normale Superieure, (3), vol. 55, no. 2 (April-June, 1938), pp. 119-191.

Theory of non-linear q-difference equations. Read Sept. 6, 1938. Annali di Matematica, (4), vol. 17, nos. 1-2 (Jan.-June, 1938), pp. 59-106.

- Analytic Theory of Non-linear Singular Differential Equations. Read Dec. 31, 1936. Mémorial des Sciences Mathématiques, vol. 90, 1938. $81 \mathrm{pp}$.

Tucker, A. W. Degenerate cycles bound. Read Sept. 9, 1937. Recueil Mathématique, (3), vol. 3 (1938), pp. 287-288.

Tuller, Annita. The measure of transitive geodesics on certain three-dimensional manifolds. Read Sept. 7, 1937. Duke Mathematical Journal, vol. 4, no. 1 (March, 1938), pp. 78-94.

Vaughan, H. E. On the class of metrics defining a metrisable space. Read Dec. 28, 1937. This Bulletin, vol. 44, no. 8 (Aug., 1938), pp. 557-561.

- On locally bicompact spaces. Read Dec. 30, 1936. Fundamenta Mathematicae, vol. 31 (1938), pp. 15-21.

Walker, R. J. See Rosser, Barkley.

Wall, H. S. On continued fractions representing constants. Read April 9, 1937. This Bulletin, vol. 44, no. 2 (Feb., 1938), pp. 94-99.

On the nth derivative of $f(x)$. Read Sept. 5, 1936. This Bulletin, vol. 44, no. 6 (June, 1938), pp. 395-398.

Walsh, J. L., and Sewell, W. E. Note on degree of trigonometric and polynomial approximation to an analytic function. Read Sept. 6, 1938. This Bulletin, vol. 44, no. 12 (Dec., 1938), pp. 865-873.

Ward, Morgan. Arithmetical properties of sequences in rings. Read April 3, 1937. Annals of Mathematics, (2), vol. 39, no. 1 (Jan., 1938), pp. 210-219. 
Structure residuation. Read Nov. 27, 1937. Annals of Mathematics, (2), vol. 39, no. 3 (July, 1938), pp. 558-568.

The law of apparition of primes in a Lucasian sequence. Read Nov. 28, 1936 and Feb. 26, 1938. Transactions of this Society, vol. 44, no. 1 (July, 1938); pp. 68-86.

Warschawski, S. E. Über die Winkelderivierten schlichter Funktionen. Read Feb. 23, 1935. Compositio Mathematica, vol. 4, no. 3 (June, 1937), pp. 346-366.

Webster, M. S. Orthogonal polynomials with orthogonal derivatives. Read Nov. 28, 1936. This Bulletin, vol. 44, no. 12 (Dec., 1938), pp. 880-887.

Wehausen, J. V. Transformations in linear topological spaces. Read Sept. 9, 1937. Duke Mathematical Journal, vol. 4, no. 1 (March, 1938), pp. 157-169.

Weiss, Paul. The self-contradictory. Read Sept. 1, 1936. Philosophical Review, vol. 47 , no. 5 (Sept., 1938), pp. 531-533.

Weyl, F. J. See Weyl, Hermann.

Weyl, Hermann, and Weyl, F. J. Meromorphic curves. Read April 16, 1938. Annals of Mathematics, (2), vol. 39, no. 3 (July, 1938), pp. 516-538.

White, H. S. Formal synthesis of two periodic correspondences, of period five and seven, respectively. Read Sept. 7, 1923. This Bulletin, vol. 44, no. 8 (Aug., 1938), pp. $562-565$.

Whitney, Hassler. Cross-sections of curves in 3-space. Read Oct. 29, 1932. Duke Mathematical Journal, vol. 4, no. 1 (March, 1938), pp. 222-226.

- On products in a complex. Read March 27, 1937. Annals of Mathematics, (2), vol. 39, no. 2 (April, 1938), pp. 397-432.

- Tensor products of abelian groups. Read Feb. 26, 1938. Duke Mathematical Journal, vol. 4, no. 3 (Sept., 1938), pp. 495-528.

Whyburn, G. T. The mapping of Betti groups under interior transformations. Read March 27, 1937. Duke Mathematical Journal, vol. 4, no. 1 (March, 1938), pp. $1-8$.

- Interior transformations on surfaces. Read Dec. 30, 1937. American Journal of Mathematics, vol. 60, no. 2 (April, 1938), pp. 477-490.

- A theorem on interior transformations. Read Dec. 29, 1937. This Bulletin, vol. 44, no. 6 (June, 1938), pp. 414-416.

- Interior surface transformations. Read April 16, 1938. Duke Mathematical Journal, vol. 4, no. 3 (Sept., 1938), pp. 626-634.

Widder, D. V. The Stieltjes transform. Read Dec. 31, 1936 and March 26, 1937. Transactions of this Society, vol. 43, no. 1 (Jan., 1938), pp. 7-60.

Wiener, Norbert. Random functions. Read Dec. 27, 1933. Journal of Mathematics and Physics, Massachusetts Institute of Technology, vol. 14, no. 1 (March, 1935), pp. 17-23.

- The historical background of harmonic analysis. Read Sept. 9, 1938. American Mathematical Society Semicentennial Publications, vol. 2, 1938. pp. 56-68.

Wiener, Norbert, and Martin, W. T. Taylor's series of functions of smooth growth in the unit circle. Read Feb. 26, 1938. Duke Mathematical Journal, vol. 4, no. 2 (June, 1938), pp. 384-392.

Wilder, R. L. The sphere in topology. Read Sept. 9, 1938. American Mathematical Society Semicentennial Publications, vol. 2, 1938. pp. 136-184.

Wilks, S. S. The large-sample distribution of the likelihood ratio for testing composite hypotheses. Read March 26, 1937. Annals of Mathematical Statistics, vol. 9, no. 1 (March, 1938), pp. 60-62.

Williams, W. L. Permanent configurations in the problem of five bodies. Read Sept. 6, 1938. Transactions of this Society, vol. 44, no. 3 (Nov., 1938), pp. 563-579. 
Williamson, John. Matrices normal with respect to an hermitian matrix. Read April 16, 1938. American Journal of Mathematics, vol. 60, no. 2 (April, 1938), pp. 355-373.

Winger, R. M. Rational curves of order $n+2$ invariant under dihedral collineation groups of order $2 n$. Read Sept. 3, 1936. American Journal of Mathematics, vol. 59, no. 4 (Oct., 1937), pp. 927-940.

Wintner, Aurel. See van Kampen, E. R.

Wolf, M. C. Transformation of bases for relative linear sets. Read Dec. 29, 1937. This Bulletin, vol. 44, no. 10 (Oct., 1938), pp. 716-718. See Ingraham, M. H.

Zariski, Oscar. Polynomial ideals defined by infinitely near base points. Read Dec. 31, 1936. American Journal of Mathematics, vol. 60, no. 1 (Jan., 1938), pp. 151-204. Zippin, Leo. See Montgomery, Deane. 